\section{Некоторые вопросы исследования работоспособности трелевочных Волоков}

\author{
Ю. А. Бит ${ }^{1}$ \\ И. В. Григорьев \\ Санкт-Петербургская лесотехническая академия
}

\begin{abstract}
АННОТАЦИЯ
В статье приводится краткое описание исследований работоспособности трелевочных волоков, описание принципиально нового прибора для измерения плотности лесной почвы, созданного в лесотехнической академии, а также результаты исследовательских испытаний по измерению плотности почвы и исследованию работоспособности трелевочных волоков, проведенных авторами в различные годы.
\end{abstract}

Ключевые слова: плотность почвы, трелевочный волок, уплотнение, колея, трелевка.

\section{SUMMARY}

The paper contains a brief description of investigations of skidding portage efficiency, a description of a fundamentally new device for measurement of forest ground density, created in the Forest Technical Academy, as well as the results of testing of ground density measurements and skidding portage efficiency, conducted by the authors at different times.

Keywords: density of ground, skidding portage, compaction, rut, skidding.

Одной из наиболее тяжелых и энергоемких операций лесозаготовок является трелевка леса вследствие большого сопротивления перемещению пачки хлыстов (деревьев).

На величину коэффициента сопротивления перемещению пачек и одиночных деревьев и хлыстов в разной мере оказывают влияние многие технологические факторы: природные, климатические, производственные, технические и другие. К природно-климатическим относятся: размеры (диаметр и длина) и порода дерева или хлыста, их кривизна, ширина и длина кроны дерева, количество, диаметр и длина сучьев и угол их отклонения от продольной оси ствола, количество и размеры подроста, физико-механические свойства древесины, захламленность лесосеки, растительный покров (мох,

\footnotetext{
${ }^{1}$ Авторы-соответственно доцент и стариий преподаватель кафедры технологии лесозаготовительных производсть
}

(C) Ю. А. Бит. И. В. Григорьев, 2001 трава, ягодник), грунты и их свойства, наличие бугорков, ям, кочек, камней, корней и других естественных неровностей на поверхности земли и трелевочного пути, сезоны года, осадки, влажность окружающей среды, состояние поверхности местности и трелевочного пути (сухая, мокрая, покрытая снегом). Производственные факторы: схема разработки делянки и расположение трелевочных волоков, способ разработки пасеки (трелевка с ближнего или дальнего ее конца от лесопогрузочного пункта), способ трелевки, вид трелюемого груза (одиночные деревья или хлысты, пачки деревьев или хлыстов), ориентация деревьев или хлыстов при трелевке (вершиной или комлем вперед), вес (масса) и объем пачки, ее линейные размеры и площадь касания с опорной поверхностью, количество деревьев или хлыстов в пачке, ширина трелевочного волока и качество его подготовки, количество пней, несрубленного подроста и других неровностей на пути движения пачки. Техническими факторами являются: марка, тип и класс трелевочной машины, ее параметры и технологическое оборудование для сбора и формирования пачки, скорость трелевки, жесткость трелевочной системы и другие.

На лесозаготовках в России преимущественное применение имеют гусеничные трелевочные тракторы, эксплуатационная надежность которых проверена на протяжении длительного периода.

При разработке лесосек с низкой несущей способностью грунтов влияние проходимости особенно велико. Под проходимостью понимается количество возможных проходов (рейсов) трактора по волоку, т.е. его работоспособность. Работоспособность связана с образованием колеи под воздействием многократных проходов машины по одному следу. Когда глубина колеи достигнет предельной величины, обусловленной лесохозяйственными требованиями и проходимостью трактора, работоспособность волока считается исчерпанной.

Работоспособность трелевочного волока оценивается общим объемом трелюемой по волоку древесины $\mathrm{Q}_{\mathrm{B}}$ до полной потери проходимости трелевочного трактора, углубления колеи на величину, большую дорожного просвета, и определяется по формуле:

$$
Q_{s}=Q_{p} N
$$

где $\mathrm{Q}_{\mathrm{p}}$ - рейсовая нагрузка трактора, ${ }^{3} ; \mathrm{N}$ - число проходов (рейсов) трактора.

Работоспособность отдельных участков волока отличается и определяется в основном физико-механическими свойствами почвы, массой трелевочной системы и способом трелевки. 
Применив соответствующие зависимости нарастания глубины колеи от числа проходов трактора, можно определить технически возможное количество проходов для заторфованных и текучих грунтов выражением:

$$
H=h+\alpha(n-1),
$$

где $\mathrm{H}$ - глубина колеи; $\mathrm{h}$ - глубина колеи от первого прохода; $\alpha$ - показатель нарастания глубины колеи от последующих проходов; $\mathrm{n}$-количество проходов.

Зависимость глубины колеи от числа проходов может определяться с помощью портативного прибораударника ДорНИИ по формуле:

$$
\mathrm{E}=1,5 \mathrm{~N},
$$

где $\mathrm{E}$ - модуль деформации проезжей части волока. МПа; N - число ударов гири ударника, необходимое для погружения наконечника на глубину 100 мм.

Недостатком данного способа является то, что на сильно увлажненных и переувлажненных почвах гиря ударника частично или полностью погружается в почву под воздействием массы ударника. Следствием этого является неточность получаемых данныг.

Для определения работоспособности волоков может быть использован ручной прибор (зонд) статического действия массой в пределах 2,5 кг.

Кафедрой технологии лесозаготовительных производств проводились исследования работоспособности волоков на ряде лесозаготовительных предприятий при работе тракторов с колесным и гусеничным движителями.

Ездовая поверхность волоков имеет характерные особенности. К ним относятся влажность, присущая всем лесным грунтам, и слоистое строение. Особенное значение имеют влажность и невысокая плотность верхнего слоя грунта. Под ним расположен минеральный слой, с меньшей влажностью и большей плотностью. Такая особенность проезжей части волока предопределяет его изменение под воздействием нагрузок. При этом можно выделить три основных этапа в процессе образования колеи: выпирание в стороны верхнего растительного слоя, который не уплотняется под нагрузкой, а выдавливается, образуя валики; значительное углубление колеи, когда под действием первых проходов основной «рабочий» грунтовой массив (нижний минеральный слой, имеющий меньшую влажность, более высокую плотность и лучшие прочностные показатели) уплотняется; уменьшение возрастания глубины колеи благодаря тому, что грунт на полосе наката достаточно уплотнен. Указанные этапы наиболее характерны для летних условий, осенью из-за повышенной влажности почвы третий этап - стабилизация глубины колеи - не наступает.
На рис. 1 отражен первоначальный интенсивный рост глубины колеи с увеличением количества проходов трелевочного трактора, вызванный разрушением верхнего и уплотнением нижнего слоя. В дальнейшем интенсивность колееобразования либо уменьшается (не переувлажненный грунт), либо увеличивается (при высокой влажности грунта). Интенсивность колееобразования усугубляется также воздействием перемещаемой волоком пачки хлыстов (деревьев), которая разрушает почвенно-растительный слой по всей ширине проезжей части.

По принятой максимально допустимой глубине колеи, обусловленной лесохозяйственными требованиями и проходимостью трактора, работоспособность волока с учетом (1) может быть определена по формуле:

$$
Q_{p}=Q_{\Pi}\left(\frac{h_{o o n} E}{a}\right)^{2},
$$

где $\mathrm{Q}_{\mathrm{p}}$ - прогнозируемая работоспособность волока, ${ }^{3}$; $\mathrm{Q}_{\Pi}$ - полезная нагрузка на рейс, $\mathrm{m}^{3} ; \mathrm{h}_{\text {доп }}$ - максимально допустимая глубина колеи, см; a - расстояние от начала волока до поперечника, на котором определяется его работоспособность.

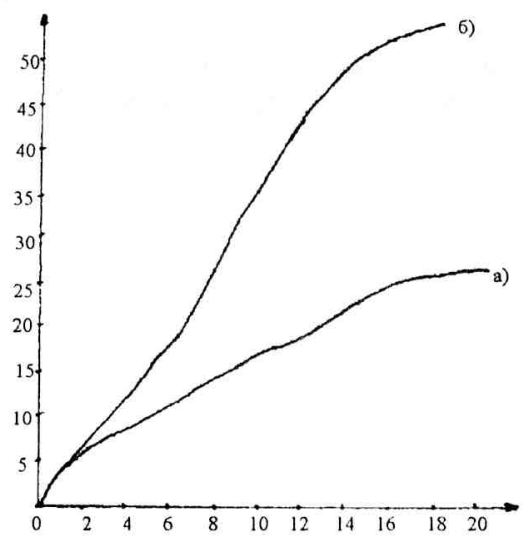

Рис. 1. Зависимость интенсивности колееобразования от числа проходов трактора ТДТ-55: а - летние условия; б- осенние условия

Используя формулу (4), можно прогнозировать возможную работоспособность волоков в зависимости от принятой системы машин и известного модуля деформации, замеренного в натуре ударником.

Работоспособность волока может быть повышена за счет его укрепления порубочными остатками.

В 1998 году'в условиях сырьевой базы Лисинского лесхозтехникума были проведены исследования состояния почвы в зависимости от ее плотности и твердости. 
Для проведения исследований был использован принципиально новый ручной прибор, созданный в СанктПетербургской лесотехнической академии.

Принцип работы устройства заключается в следующем. Для снижения сопротивления резанию почвы, пронизанной корнями растений, и сохранения структуры образца (керна) цилиндрический нож под воздействием усилий, прилагаемых исследователем на ручные и ножные упоры. совершает поступательное движение в почву. После предельного погружения прекращается воздействие на упоры, устройство вместе с керном извлекается из почвы и с помощью выталкивателя керн удаляется из цилиндрического ножа.

Производственные испытания проводились на проходных рубках в октябре месяце. Площадь лесосеки 3.0 га, ликвидный запас $-150 \mathrm{~m}^{3} /$ га, состав насаждений -6 Б3С ІЕ+С+Б, средний объем хлыста $-0,18 \mathrm{~m}^{3}$, бонитет -11 .

Использовалась технологическая схема: валка - обрезка сучьев - трелевка - раскряжевка. На валке, обрезке сучьев и раскряжевке использовались бензиномоторные пилы, на трелевке - трактор ТДТ-55. Погрузка сортиментов и вывозка производились самопогружающимися сортиментовозами.

Исследуемые пасечные волока были разбиты на пикеты с расстоянием между ними 1 м. После каждого прохода трактора на каждом пикете брались пробы лесной почвы, которые помещались в герметично закрывающиеся пакеты и снабжались бирками, на которых указывались: № волока, № пикета и № прохода трелевочного трактора. Образцы взвешивались в лабораторных условиях и данные заносились в журнал испытаний.

До первого прохода трактора на волоках измерялась естественная плотность почвы. Затем она замерялась после каждого прохода трактора с пачкой. Одна колея была покрыта порубочными остатками, а другая - очищена от них.

Плотность отобранных образцов почвы определялась по формуле:

$$
\rho=\frac{m}{V},
$$

где $\rho$ - плотность керна почвы; $m$ - масса керна почвы; $\mathrm{V}$ - объем керна почвы.

Помимо измерения плотности почвы во время проведения эксперимента после каждого прохода трелевочного трактора делались замеры глубины и ширины образующейся колеи.

На рис. 2. представлен график зависимости плотности почвы от числа проходов трелевочного трактора по покрытой и не покрытой порубочными остатками колее. Из него можно видеть влияние порубочных остатков на уплотнение почвы, а следовательно, и глубину колеи.

На рис. 3. представлен график распределения плотности лесной почвы, естественной и после окончания разработки лесосеки. Из данного графика видно, что в месте примыкания пасечного волока к магистральному плотность почвы увеличивается (нумерация пикетов начиналась от магистрального волока), что объясняется большим числом проходов трелевочного трактора по данному участку.

Из сказанного выше можно сделать вывод, что правильный выбор трассы волока и укрепление его порубочными остатками оказывают существенное влияние на повышение его работоспособности.

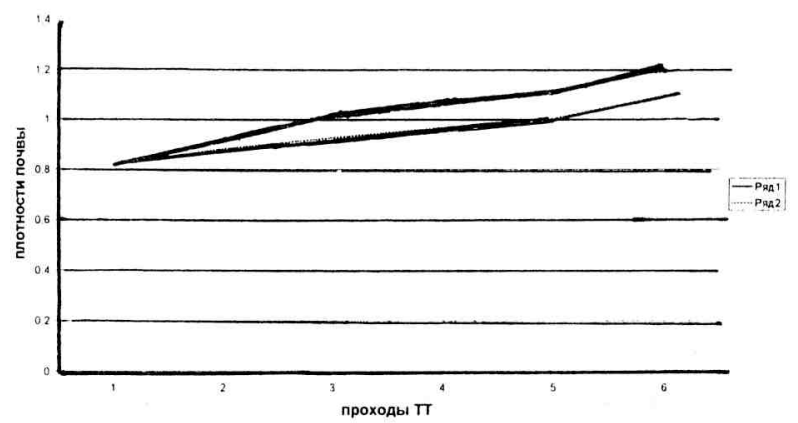

Рис. 2. Зависимость плотности почвы от числа проходов ТТ: ряд 1 - колея без порубочных остатков, ряд 2 колея с порубочными остатками

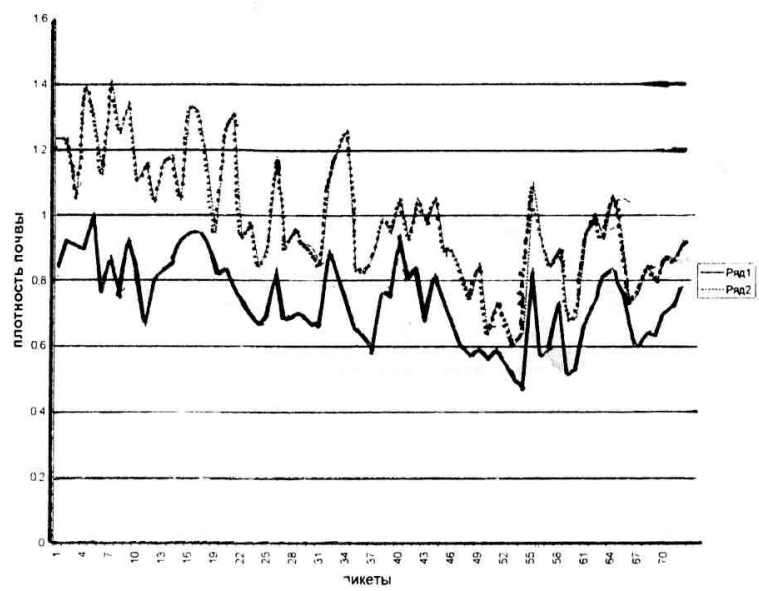

Рис. 3. График распределения плотности почвы по длине волока: ряд 1 - естественная плотность почвы, ряд 2 - окончательная плотность почвы 